\title{
Overview
}

Psychopathology

\section{Phenomenology of Obsessive-Compulsive Disorder: A Methodologically Structured Overview}

\author{
Martin Bürgy \\ Center of Mental Health, Klinikum Stuttgart, Stuttgart, Germany
}

\section{Keywords \\ Phenomenology · Methodological order · Understanding · Obsessive-compulsive disorder - Overview}

\begin{abstract}
A methodological order is derived from the concept of phenomena and stages of understanding are developed according to Karl Jaspers. The three levels of descriptive, genetic and hermeneutic understanding are applied to the study of obsessive-compulsive disorder. Descriptive understanding essentially reveals a sense of incompleteness and depersonalization that underlies the experience of the nonsense of obsessive thoughts and that obsessive-compulsive symptoms do not come to an end. Genetic understanding shows particularly by reference to the trigger situation that sensitivity, undifferentiated affects, affective hyperarousal and traumatization are important aspects in the development and maintenance of the obsessive-compulsive disorder. Hermeneutic understanding brings to light the fear of death in obsessive-compulsive disorder as its anthropological dimension. The aim of this methodologically structured overview is to focus on the experience of the obsessive-compulsive patient, to keep curiosity and interest alive, so that both research and relationship to the patient is stimulated.
\end{abstract}

๑) 2019 S. Karger AG, Basel

\section{Introduction}

The operationalization of psychiatric diagnostics has undoubtedly led to an increase in reliability and to the end of the "Babylonian language confusion" in psychiatry [1-3]. A manageable number of criteria that can easily be distinguished from each other provides diagnostic certainty and enables sufficient success in times of scarce economic and human resources, but it must be warned that validity of diagnoses should not be sacrificed to the necessary simplification [4]. If diagnoses describe inaccurately what they claim to describe and their hypothetical character is lost, then therapy and the relationship with the patient run the risk of becoming diffuse and ineffective. It therefore remains the task of phenomenology to establish contact with the patient's experience again and again, to keep the knowledge about the complexity of psychic symptoms alive and thus to constantly update our clinical knowledge.

The present study therefore aims first to give a brief description of what phenomenology is; second, to develop a phenomenological framework for the investigation of mental symptoms; and third, to provide an overview of

Dedicated to Prof. Dr. Dr. Hermann Lang to his 80th birthday.

\section{KARGER}

E-Mail karger@karger.com

www.karger.com/psp
Prof. Dr. Dr. Martin Bürgy, MSc

Clinic for Special Psychiatry, Social Psychiatry and Psychotherapy

Center of Mental Health, Klinikum Stuttgart, Priessnitzweg 24

DE-70374 Stuttgart (Germany)

E-Mail m.buergy@klinikum-stuttgart.de 
the current state of a phenomenology of obsessive-compulsive disorder based on this methodological framework. The aim is to achieve an understanding of the complexity of the obsessive-compulsive symptoms, how they develop in the patient and what anthropological significance they have.

\section{A Brief Description of What Phenomenology Is}

What the term "phenomenology" actually means is not immediately clear. There is no uniform phenomenological methodology, but only a multitude of different methods [5-7]. If we try to bring the heterogeneous phenomenological approaches together, then it is reasonable to use the epistemological structure of the phenomenon concept. "Phenomenon" refers to what appears to the subject. Thus, the polarity of imagining consciousness and imagined object is brought into view [8]. In the following, we will try to outline this polarity on the basis of some milestones of phenomenological philosophy.

Historically, Hegel [9] was the first philosopher presenting a systematic study on "Phenomenology of the Spirit" in 1807 . Here the polarity mentioned can be found in the sense of an absolute spirit that materializes in history and thus appears in the consciousness of mankind [9]. In the "Encyclopedia of Philosophical Sciences," Hegel substantially changes this concept of phenomenology and refers it to subjective consciousness and its development. In the polar interrelationship of for-itself (für-sich) and onitself (an-sich) consciousness becomes itself [10].

With his "Logical Investigations" published in 1900, Husserl [11] became the actual founder of phenomenological philosophy, which he conceptualized as fundamental science. His first goal was to describe the objects given to consciousness as precisely as possible and to struggle for the congruence of imagination and concept [12]. Husserl called this approach "descriptive psychology." Jaspers transferred the "descriptive method" to psychopathology in 1912 and thus created the preconditions for the significance of subjective experiences in psychiatric diagnostics $[13,14]$.

Phenomenology in psychiatry is therefore initially no more and no less than the perception and description of what the patient experiences. Husserl later developed the phenomenological method from the pole of description to the pole of constituting consciousness. The philosophy of his former scholar Heidegger also developed in a similar way, from the initial focus on facticity to his later occupation with existential hermeneutics $[15,16]$.

Phenomenology of Obsessive-Compulsive Disorder
To this day, phenomenology has been determined by this methodological polarity, by a descriptive approach to the object on the one hand and by a hermeneutic approach based on the valuation through consciousness on the other [17]. Jaspers and his clinical followers, above all Schneider, focused on the descriptive method and thus significantly influenced the development of psychiatric classification. Essential for descriptive phenomenology, which can be traced back to Jaspers, are the strict context of experience, the rejection of theoretical assumptions and explanations as well as the boundary and order of phenomena [18]. The exclusion of hermeneutic approaches was mainly done to eliminate speculative insights [19], but in the course of time hermeneutic approaches became an integral part of phenomenology, especially in the context of phenomenological-anthropological psychiatry $[7,20,21]$.

\section{A Phenomenological Framework for the Investigation of Mental Symptoms}

The polarity in the concept of phenomenology, between descriptive and hermeneutic approaches, has been made accessible to psychiatry in a broad concept of understanding, especially by Jaspers. In his "General Psychopathology," we find three different modes of understanding, which Jaspers further elaborated as levels of understanding from the first edition in 1913 [22] to the last edition he published in 1959 [23].

The first level is that of "static understanding." Static understanding focuses on the experiences of the patient in the here and now and is descriptive phenomenology. The term "description" has become established in the further development of diagnostics and classification; in the following, we will therefore use the term "descriptive understanding" exclusively.

The second level is the level of "genetic understanding." Genetic understanding investigates "how mental phenomena emerge from each other," i.e., how symptoms arise and how they are interconnected with personality and life history. Jaspers introduces "empathetic understanding" first as an independent method, but later assigned it to genetic understanding.

Jaspers initially calls the third level of understanding "understanding and interpreting" and later renames it "grasping the wholeness." By this he means that research which deals with the individual and the particular cannot dispense its orientation towards the whole, meaning and sense. This third level of understanding is therefore synonymous with "hermeneutic understanding." 
The three described modes of understanding are based on each other and are intertwined. Descriptive understanding deals with the immediate experience of the patient in the situation under examination and therefore enables the highest level of evidence ${ }^{1}$. On the path of phenomenological investigation, understanding increasingly moves away from the current contents of consciousness, focuses on the emergence of symptoms in the patient's own and external anamnesis, and finally attempts to grasp the meaning of the disease. On the one hand, this makes understanding more speculative, but on the other hand, the results become more complete [25]. The hermeneutic circle tries to connect the levels of understanding in a movement from the individual to the whole, from the symptoms and their development to their meaning [26]. This approach has not yet been realized.

Blankenburg [5] writes in 1991 in a late article about perspectives of psychiatric phenomenology. "For the future it will remain an important task to bring descriptive and genetic or hermeneutic phenomenology into close connection with each other (p.99)."

\section{An Overview of the Current State of a Phenomenology of Obsessive-Compulsive Disorder}

The levels of understanding developed with Jaspers are intended to help in ordering obsessive-compulsive phenomena from the descriptive to the hermeneutic pole and to interrelate them with each other. The concept of the phenomenon focuses mainly on the primary experience and threatening side of the obsessive-compulsive disorder (predominantly obsessive thoughts), but is also extended to the expressive and defensive side (predominantly compulsive actions).

\section{First Level: Descriptive Understanding}

Descriptive understanding focuses on the symptoms of obsessive-compulsive disorder first described by Esquirol [27] in 1839. Esquirol portrays the fear of a young woman that something valuable might have got into her pocket unnoticed or got stuck on her, so that she develops a fear of touch and washing compulsions. He emphasizes the two characteristics, i.e., the constant struggle against

\footnotetext{
1 The concept of evidence used here is oriented towards Husserl and means the actual experience in which "the things and facts concerned are present to me as they themselves are" [24].
}

obsessive thoughts, while at the same time recognizing their ridiculousness. The obsessive phenomena are dealt with under the French term "Les obsessions."

The interest in obsessive-compulsive disorder reached Germany via Esquirol, Falret and Janet, so that in 1867 v. Krafft-Ebing [28] introduced the concept of obsessive ideas [29]. He thus describes an obsession that the melancholic mood exerts on the imaginations. In 1868, Griesinger [30] describes 3 patients with obsessive-compulsive beliefs who are not carried by emotions in a lecture to the Berlin Medical-Psychological Society. In 1877, Westphal [31] gives a lecture at the same place "On obsessive ideas" (Über Zwangsvorstellungen) and provides the first definition of obsessions, which was modified but is still valid today.

"By obsessive ideas I mean those which, by the way, with intact intelligence and without being caused by an emotional or affect-like state, step into the foreground of consciousness against the will of the person in question, do not allow themselves to be frightened away, hinder and thwart the normal course of ideas which the afflicted person always recognizes as abnormal, alien to him, and which he faces with healthy consciousness (p. 669)."

Westphal's definition becomes the basis for the discussion of obsessive-compulsive phenomena in the Germanspeaking world [32]. As late as 1939, Schneider [33] in his work "Conceptual investigation of obsessions" (Begriffliche Untersuchung über den Zwang) dealt extensively with Westphal and reached a "core definition," which is linguistically of greater sharpness. "We speak of obsessions when someone cannot suppress the contents of consciousness, although he judges them to be senseless or dominant without reason" (pp. 23-24).

Schneider has thus not only created the prerequisite for the diagnostic differentiation from delusional and affective disorders, but also an orientation that is still valid today for the diagnostic exploration of obsessive-compulsive syndromes. The definition has found its way into psychiatric classification systems, although further modifications have been made since then.

ICD-10 [34] and DSM-5 [35] differentiate between obsessions and compulsions. Obsessive thoughts include ideas, conceptions and impulses, compulsive actions in DSM include both observable behaviors and mental actions. ICD-10 clearly separates obsessive thoughts and compulsive acts from each other, thus ignoring the fact that obsessive thoughts and compulsive acts nearly always occur together [36]. DSM-IV [37] classifies obsessive-compulsive disorder as an anxiety disorder and thus constitutes a dynamic relationship of primary obsession, usually obsessive thoughts that cause anxiety, and sec- 
ondary compulsion, usually compulsive acts that serve to cope with anxiety [38]. DSM-5 removes the classification of obsessive-compulsive disorders as anxiety disorders, introduces a new section "obsessive-compulsive and related disorders" with different degrees of insight into the absurdity of obsessions. The view remains that obsessive thoughts are the precondition for compulsive actions [39]. The category "lack of insight" is found in $4-6 \%$ of cases, but in comorbidity to schizophrenic and delusional disorders and is therefore doubtful in its application to obsessive-compulsive disorder [40].

As early as 1903, Janet [41] established the inner connection between obsessive ideas (idées obsédantes) and the compulsions they entail (agitations forcées). In 1936, Binder [42] spoke of a strangely persistent disturbance experience, which cannot be neutralized by defensive measures, and Schneider [33] in 1939 spoke more neutrally of primary and secondary compulsions. Authors such as Lang [43] in 2015 and Hoffmann and Hofmann [44] in 2018 have further investigated the interplay between the threatening and the defensive side. The distinction between primary and secondary compulsions is also important for differential diagnosis. While on the action level mostly unspecific symptoms, especially washing, checking and order compulsions, are impressive, only the investigation of primary phenomena enables the more exact differentiation between obsessive thoughts and delusion [45].

The described structure of obsessive-compulsive disorder has found its way into further attempts at differentiation, e.g., through the factor-analytic differentiation of dimensions which, despite their differences, have relatively consistent forms and contents [46-49]: (1) fear of contamination and cleaning compulsions; (2) forbidden thoughts and checking compulsions; (3) symmetry obsessions and ordering compulsions; and (4) collecting and hoarding. In the following, the clinical observation of the phenomena demonstrates that the interrelationships between obsessive thoughts and compulsive actions are different than initially assumed by factor analyses.

\section{Fear of Contamination and Cleaning Compulsions}

The investigation of the washing and cleaning compulsions shows that these are not only based on a threatening fear of contamination, but rather on disgust with potential or actual contact. The more exact examination of the fear of infection and disease makes this recognizable as a secondary rationalization of a primary disgust sensitivity. v. Gebsattel [50] had already described the "disgust phobia of the obsessively ill" in 1954 and based the washing compulsions on it.

Phenomenology of Obsessive-Compulsive Disorder
Forbidden Thoughts and Checking Compulsions

The checking compulsions are based on forbidden thoughts of an aggressive, sexual or religious nature that are symbolically fought against in an act of externalization as a threat. However, the decisive factor for not being able to stop the compulsions is the feeling of incompleteness, which Janet first described in obsessive-compulsive disorder [51, 52]. The control of electrical appliances and sockets, for example, does not come to an end because neither affect nor insight can be established that the action has been completed. The patient suffers from the conviction that a permanent danger emanates from him, which always seeks and finds new contents.

\section{Symmetry Obsessions and Ordering Compulsions}

The repetition and order compulsions are based on the threatening of thoughts about blasphemy, serious offences of one's own, illness, pollution, contamination and shame concerning one's own person or body. The compulsive actions try to neutralize the threatening side and cannot be finished due to the experience of incompleteness [52]. The disturbance phenomenon is not characterized by the fear, for example, of the outbreak of a fire or the accident of a close relative, but by the fear that oneself could have caused the fire or the accident without noticing. Thinking is magical, there are gaps in self-perception. Consciousness and attention are not reliable.

\section{Collecting and Hoarding}

Compulsive collecting and hoarding refers to objects of relatively low value that over time fill living spaces and render them unusable for living. Secondary rationalizations are economy or precaution against times of need. There is an intimate relationship with the objects for which the patient feels responsible and to which he sometimes ascribes mental feelings. The defensive side is the creation of security against the threatening dissolution and emptiness by dispensing with "storage behaviour." Authors such as Lang [53], Quint [54] and Bürgy [55] have based this phenomenon causally on a "disturbance of the self" or on an "integration weakness of the ego." Since each factor and cluster analysis replicated the dimension of compulsive hoarding, this led to a separate diagnosis in DSM-5.

The common feature of these obsessive-compulsive phenomena remains the incompleteness related to one's own person, not being right, not being quite there, that actions cannot be completed and run the risk of damaging others. Hoarding and collecting can be seen as attempts to overcome one's own incompleteness and emp- 
tiness, as washing and cleaning are attempts to overcome feelings of disgust, fear of confusion and dissolution. The experience of depersonalization plays a particular role in nonclosable compulsions, in phobic avoidance of the "disgusting substance," in the magical idea of harming other people, or in the increasingly urgent obsessive ideas. The importance of depersonalization in obsessive-compulsive disorder has already been emphasized by the Argentinean psychopathologist Héctor Pelegrina [56].

Disgust and the experience of incompleteness have meanwhile not only been included in the DSM- 5 classification, but also determine current research on the genesis of obsessive-compulsive disorder.

Cognitive-behavioral models are the most widely accepted theories in understanding obsessive-compulsive disorder [57]. Prominent behavioral therapists such as Salkovskis [58] and Rachman [59] consider obsessivecompulsive disorder to be a dimensional deviation from normal intrusive thoughts. They interpret obsessivecompulsive disorder as the result of wrong valuations and as a vicious circle of defensive measures. They thus follow a psychiatric tradition that understands nonpsychotic or neurotic disorders as dimensional deviations from the norm [19]. The phenomenological perspective, on the other hand, makes a qualitative-categorical difference between health and illness. Obsessive-compulsive disorders arise primarily from a broad experience of the incompleteness in feelings, thoughts, and actions. This experience cannot be completed. The affected persons experience themselves either as a permanent source of danger for the outside world and thus as guilty, and/or they are internally endangered by an endlessly transferable and permanently effective "disgusting substance" that threatens to destroy them.

\section{Second Level: Genetic Understanding}

Genetic understanding investigates how obsessivecompulsive symptoms develop and how they emerge from personality and its live history. It is usually collected retrospectively and is therefore of less evidence than descriptive understanding. The trigger situation at the interface of personality, life history and symptom formation is of particular importance.

Until the eighties of the 20th century, the opinion persisted that obsessive-compulsive personality was the prerequisite for the development of obsessive-compulsive disorder [60]. However, the available studies on comorbidity indicate that there is no direct link between obses- sive-compulsive personality and obsessive-compulsive disorder [61]. In a review published in 2013, Gordon et al. [62] concluded that only $23-34 \%$ of obsessive-compulsive disorder cases have obsessive-compulsive personality. In their own investigations, they find a corresponding comorbidity in $45 \%$ of the cases. However, there are indications that comorbid patients are characterized by earlier onset, more severe symptoms and increased familial incidence of obsessive-compulsive disorder $[63,64,65]$.

Zaudig [66] discusses a correlation between obsessivecompulsive disorder and an uncertain, anxious-avoiding and anacastic personality. Kretschmer, Jaspers and Schneider had identified sensitive traits as a precondition for obsessive-compulsive disorder. In 1986, Lang [53] extended the psychoanalytical view of oedipal conflict and anal regression to include the social view of the obsessivecompulsive person as an "inhibited rebel," who is above all structured by the conflict "autonomy versus submissiveness," by deep fears of powerlessness, overorderliness, latent aggressiveness, and revolt.

Janet has placed the obsessive-compulsive disorder in the context of "psychasthénie," a syndrome that in ICD10 most closely corresponds to neurasthenia. By this, he means a stress-dependent decrease in tension, which leads to the fact that the combination of the individual moments of reality is impaired to a meaningful whole. This leads to restlessness, doubt, fear and obsessive thinking, and the appearance of the above-mentioned "feeling of incompleteness."

Empirical studies were stimulated by Summerfeldt's [67] 2004 model, which emphasizes two motivational-affective core dimensions in obsessive-compulsive disorder: The dimension "harm avoidance," which has obsessive-compulsive disorders in common with anxiety disorders, and the dimension "incompleteness," which seems to be specific for obsessive-compulsive disorder $[68,69]$. The not-just-right experience is the anacastic variant of incompleteness [70]. It is the merit of Hoffmann [71] to have rediscovered Janet's feeling of incompleteness in 1998 and to have related it to self-experience. Hoffmann and Hofmann [44] use the term "incompleteness related to one's own person" to refer to a specific form of depersonalization/derealization that is specific to obsessive-compulsive disorder. Ecker et al. [72] elaborated the "Questionnaire on the Self-Related Experience of Incompleteness" in 2013. With incompleteness they describe an inner state difficult to put into words and not yet definitively defined, which contributes to the fact that actions, thoughts and feelings are experienced as incomplete and cannot be finished. It seems to be a motivation- 
al core dimension of obsessive-compulsive disorder, the severity of which correlates with the frequency of the obsessive-compulsive symptoms [73] and which at the same time establishes a connection to the obsessive-compulsive personality and to other disorders of the obsessivecompulsive spectrum $[74,75]$.

The experience of depersonalization and derealization plays a special role not only in the maintenance of obsessive-compulsive symptoms, but above all in the trigger situation which best describes the inner condition in the case of obsessive-compulsive disorder. As early as 1909, Freud [76] described in his publication "Remarks on a case of obsessive-compulsive disorder" (Bemerkungen über einen Fall von Zwangsneurose) the original struggle of intense contradictory feelings, above all of love and hate. According to Freud, this leads to strong uncertainty, ambivalence, paralysis of the will, and neurotic symptom formation in the form of symbolic obsessive-compulsive acts. The obsessive thought is secondarily isolated from affect, so that almost no affect can be found anymore. Binder [42] attributed the triggering of obsessive-compulsive symptoms to a weakness of integration, v. Gebsattel [77] to the disintegration of affects. Hoffmann and Hofmann [44] emphasize the intensity of feelings and their confusion at the onset of the disorder. In the experience of the patient, affects such as pain, sadness, loneliness, fear, disgust and anger are named above all. Bürgy [78] has described the trigger situation as follows: The basis is formed by insecurity, anxiety, and inhibition deeply rooted in personality. This is associated with constant inner tension and insufficient differentiation of affects, which means the poorly developed ability to identify, express and communicate affects. In a vulnerable situation of emotional overload, confusions of contradictory affects occur, which take over in a vicious circle of powerlessness, helplessness, and isolation. The strong affects attach themselves to a biographically significant object to bind the inner chaos, while compulsive actions additionally attempt to restore lost control. However, the strengthening of defense does not lead to reassurance, but depersonalization and experience of incompleteness, so that no conclusion is reached. Obsessive-compulsive worlds of magical-irrational character spread out, so that increasingly a life emerges in two worlds separated from each other [25].

The trigger situation paradigmatically exemplifies the recurring activatability of the constraints and may contain a traumatic component. Finally, there is increasing reference in the literature to a close connection between obsessive-compulsive disorder and trauma. In a review of

Phenomenology of Obsessive-Compulsive Disorder
2014, Dykshoorn [79] reports that patients with obsessive-compulsive disorder have comorbidity with posttraumatic stress disorder in about $30 \%$ and comorbidity with posttraumatic stress disorder and traumatic experiences in $30-82 \%$. Individuals in the obsessive-compulsive disorder and posttraumatic stress disorder group reported more severe obsessive-compulsive symptoms, poorer insight, lower quality of life and greater incidences of lifetime mood and substance abuse disorders [80].

The psychopathology of obsessive-compulsive disorder and posttraumatic stress disorder shows clear overlaps. Both diagnostic groups suffer on intrusive thoughts, urges, or images experienced as unwelcome and invasive. The intrusions are associated with feelings of guilt and disgust. Individuals with obsessive-compulsive disorder and posttraumatic stress disorder actively try to avoid, subdue, or neutralize both, intrusions and trigger situations. Both groups suffer from an internal affect confusion and hyperarousal. A certain plausibility arises for the view that the core of the feeling of incompleteness is based on traumatic experiences.

Cognitive behavioral therapy is not only a widely accepted treatment for posttraumatic stress disorder and obsessive-compulsive disorder, but always implicitly integrates the traumatic component in the therapy of obsessive-compulsive disorder. Thus, behavioral therapy counters internal confusion with exposure and ritual prevention as well as with the treatment of dysfunctional convictions [81]. Hoffmann and Hofmann [82] are also concerned with the differentiation of the muffled and clotted affects experienced, with the concentrated restoration of reality, with focusing and reinstating the normal laws of the interpersonal. The problems should be solved in the real and not in the magical world. The "self-system" is to be activated, which comprises the previous, normal experiences, feelings, convictions and values. The fragmentation is to be removed by narrative production of emotional continuity in the life story. First experiments with trauma-specific eye movement desensitization and reprocessing therapy show results equivalent to cognitive behavioral therapy and better than drug strategies with selective serotonin reuptake inhibitors [83, 84].

\section{Third Level: Hermeneutic Understanding}

Hermeneutic understanding aims to identify the meaning or sense of obsessive-compulsive symptoms and their anthropological dimension. Although this approach has the weakest evidence, it is able to connect descriptive 
and genetic aspects with a common bond. The primary threatening side of obsession is characterized by a helpless state described as affect-confusion, fear of dissolution, depersonalization, and feeling of incompleteness. In combination with the defensive and coping side, there is an inability to complete actions and a disturbance of the temporal becoming. The past cannot be closed, whereby life freezes in a helpless, repetitive action. The dimension of the future is lost, the sick person is locked up in the present. According to v. Gebsattel [77], human transience therefore presses with power into the consciousness of the obsessively ill. "In the case of the obsessively ill, the past does not take on the perfect form; as the incomplete, it pushes forward and floods the sick in the symbols of the impure, the dirty, or the dead" (p. 144).

In his recent contribution, Otto Doerr-Zegers [85] described the circularity and sterility of the obsessive experience of time and the tendency to diminish distance and concede space. These considerations lead over to the issue of death as the anthropological dimension of obsessivecompulsive disorder.

In 1938, Erwin Straus [86] published the self-reporting of a patient, in which the development of obsessive-compulsive washing results from an original fear of death, which is secondarily shifted into the experience of disgust. In 1965, Skoog [87] found confusing motives for death in more than $70 \%$ of the obsessive-compulsive patients he specifically interviewed, while Schwidder [88] saw the central threat to the obsessively ill in 1972 in a death that could break out unexpectedly at any time. Even in current publications, for those who are affected, the subject of death gains importance. Common death symbols such as crosses, people in mourning clothes, hearse, cemeteries, etc. cause strong discomfort and the magical expectation of disaster among the sick. Behind washing compulsions, fear of decay, illness and death is often hidden and sometimes mixed with disgust [89]. Menzies et al. [90] pointed out in 2015 that fear of death plays a particularly important role in washing and checking compulsions, in fear of contamination, in disgust sensitivity, in fear of fire and burglary. In a study of 183 patients with obsessive-compulsive disorder, they were able to show with the Vancouver Obsessive Compulsive Inventory and the Collett-Lester Fear of Death Scale that in patients with obsessive-compulsive disorder there is a strongly increased fear of death as well as a close correlation between the severity of obsessive-compulsive symptoms and the severity of fear of death [91]. The authors derive from this the demand to integrate the fear of death into the treatment, e.g., with imaginative methods [92].
The Göttingen psychiatrist J.E. Meyer [93, 94] dealt most extensively with the motif of death. In his opinion, the phobic element occurring in the initial phase of obsessive-compulsive disorder refers to the avoidance of a death that is always immanent in life. While with v. Gebsattel the obsessively ill person is stuck in the past due to defense and avoidance, with Meyer the fear of the future blocks his personal self-development. Human existence cannot become what it is without self-development. Man gets into a vicious circle of fear, avoidance and rebellion in the face of his unlived life.

Meyer [95] described obsessive-compulsive disorder as "thanatophobic neurosis" and thus provided an interpretation that is also reflected in Hermann Lang's structural-anthropological approach. Lang takes up Freud's idea of the special significance of the death drive in obsessive-compulsive disorder and, with the example of Shakespeare's drama character Lady Macbeth, develops the significance of the compulsive washing as a rebellion against guilt and certain death [96]. According to Meyer, the fear of dying and death is found in the fear of the decomposable, dirt and dust, as well as in the fear of the definitive, unrepeatable and unpredictable of life. Fear of death is also hidden behind the hopeless and exhaustive struggles of compulsive actions, as well as behind extreme caution, care and vigilance. The defense systems block a more original, spontaneous experience that cannot be left to the moment with its dangers but also its possibilities.

In my opinion, there is a close connection between the mortal fear of the obsessive-compulsive patient and his experience of depersonalization, confusion and fractionation of self-experience. Depersonalization is characterized by the feeling of "not being properly present oneself," "experiencing oneself as alien," "looking at oneself from the outside," "being like a robot," "no longer acting oneself," "dissolving oneself." Depersonalization therefore always brings experience close to death and dying.

\section{Conclusion}

Based on the epistemological structure of phenomenological approaches, levels of understanding were developed with reference to Jaspers and then applied to the investigation of obsessive-compulsive disorder.

On the first level, the structure of the obsessive-compulsive symptoms was described with the help of descriptive understanding. The disturbance or threatening side was brought into focus, which is characterized by intrusive obsessive thoughts with more or less nonsensical or 
unwanted content. This characterization is still important today in the diagnostic exploration of obsessivecompulsive symptoms. Compulsive acts follow obsessive thoughts as an attempt to overcome fear and tension. The phenomenological perspective broadens the dimensional view of obsessive-compulsive disorder by investigating the particular quality of obsessive-compulsive symptoms. Obsessive thoughts are not a quantitative deviation of normal thoughts, but arise from an experience of depersonalization and incompleteness in one's own feelings, thoughts and actions. Obsessive thoughts and the resulting compulsive actions, which represent defense and coping strategies, are therefore not conclusive. The person with obsessive-compulsive disorder feels guilty of being a permanent source of danger for others and/or of being endangered himself by an endlessly effective "disgusting substance."

On the second level, genetic understanding describes the lack of differentiation of affects and the inner tension rooted in a deeply insecure and inhibited personality and it's striving for autonomy. The excessive demands in a conflict-laden triggering situation lead to the confusion of contradictory affects, which build up in a vicious circle of helplessness, isolation and rebellion and lead to depersonalization. The increasing confusion and depersonalization lead to the loss of the first person's demarcation that inside and outside, one's own and foreign, are no longer separated from each other. In the magical consciousness there are contents about the unnoticed damage of other persons or the presumption of unnoticed own contaminations. There is some evidence of a traumatic genesis of obsessive-compulsive disorder, both in terms of increased traumatic events and in terms of symptom overlap between obsessive-compulsive disorder and posttraumatic stress disorder.

On the third level, the hermeneutic understanding shows the "thanatophobia" of the obsessively ill person. The investigation of time experience indicates that feelings of incompleteness and defensive measures inhibit detachment from the past and thus future life. The fear of death is the fear that one's own life with all its possibilities will remain unlived. If we take the traumatic genesis, the confusion of affects and the resulting depersonalization as the starting point of our considerations, then the question must be allowed, whether recurrent contact with the trigger does not again and again lead to re-traumatization, to confusion of self-experiencing, depersonalization and never-ending defensive measures, which hold into the fear of death and into the anticipation of dying. Everything that symbolizes death and transience then be- comes a trigger for the reactivation of traumatization, which itself is experienced as psychic death.

The disturbing or threatening side of obsession thus permeates all stages of understanding up to and including the increasingly obvious fear of death, which is finally averted by the separation from obsessive worlds and hardly balanced by meaningful life. In the hermeneutic circle, descriptive, genetic and hermeneutic aspects can be connected and related to each other. The result is both an analytical order of the obsessive-compulsive symptoms in their structure, their genesis and their hermeneutics as well as their synthesized connection in the central symptom of traumatic confusion and depersonalization. The therapeutic and anthropological goal is for the obsessive-compulsive patient to face up to his fear of death, which is based on depersonalization, emotional chaos and traumatic overwhelming, which also emerges as a feeling of self-referential incompleteness in the description of the obsessive thoughts and the resulting compulsive actions. A modified therapy will have to include these aspects in its orientation towards clinical phenomena. The phenomenological approach always remains provisional and hypothetical but is intended to bring us into contact again and again with the experiences of this group of patients suffering from obsessive-compulsive disorder. It is my particular concern to keep the curiosity and the interest in experiences of the obsessive-compulsive patients alive.

\section{Discloser Statement}

The author has no conflicts of interest to declare.

\section{Funding Sources}

The author received no funding and no sponsoring.

\begin{tabular}{|c|c|}
\hline References & $\begin{array}{l}1 \text { Spitzer RL. Values and assumptions in the de- } \\
\text { velopment of DSM-III and DSM-III-R: an in- } \\
\text { sider's perspective and a belated response to } \\
\text { Sadler, Hulgus, and Agich's "On values in re- } \\
\text { cent American psychiatric classification". J } \\
\text { Nerv Ment Dis. } 2001 \text { Jun;189(6):351-9. } \\
2 \text { Kendell R, Jablensky A. Distinguishing be- } \\
\text { tween the validity and utility of psychiatric di- } \\
\text { agnoses. Am J Psychiatry. 2003 Jan;160(1): } \\
4-12 \text {. } \\
3 \text { Jäger M, Frasch K, Becker T. Die Krise der } \\
\text { operationalen Diagnostik in der Psychiatrie. } \\
\text { Nervenarzt. } 2008 \text { Mar;79(3):288-94. }\end{array}$ \\
\hline
\end{tabular}


4 Andreasen NC. DSM and the death of phenomenology in America: an example of unintended consequences. Schizophr Bull. 2007 Jan;33(1):108-12.

5 Blankenburg W. Phänomenologie als Grundlagendisziplin der Psychiatrie. Fundamenta Psychiatrica. 1991;5:92-101.

6 Fuchs T. The challenge of neuroscience: psychiatry and phenomenology today. Psychopathology. 2002 Nov-Dec;35(6):319-26.

7 Kraus A. Phenomenological-anthropological psychiatry. In: Henn F, Satorius N, Helmchen $\mathrm{H}$, Lauter H, editors. Contemporary Psychiatry. Berlin: Springer; 2001. vol. 1, p. 339-56.

8 Schischkoff G, editor. Philosophisches Wörterbuch. 22nd ed. Stuttgart: Kröner; 1991.

9 Hegel GW. Phänomenologie des Geistes (1807). Meiner (Hamburg): Meiner; 1988.

10 Schalhorn C. Hegels enzyklopädischer Begriff von Selbstbewusstsein. Hegel Studien. Beiheft 43. Hamburg: Meiner; 2000.

11 Husserl E. Prolegomena zur reinen Logik. Logische Untersuchungen. Volume 1. Halle: Niemeyer; 1900.

12 Husserl E. Untersuchungen zur Phänomenologie und Theorie der Erkenntnis. Niemeyer. Logische Untersuchungen. Volume 2. Halle: Niemeyer; 1913.

13 Jaspers K. Die phänomenologische Forschungsrichtung in der Psychopathologie. Z Gesamte Neurol Psychiatr. 1912;9(1):391-408.

14 Langenbach M. Phenomenology, intentionality, and mental experiences: Edmund Husserl's Logische Untersuchungen and the first edition of Karl Jaspers's Allgemeine Psychopathologie. Hist Psychiatry. 1995;6: 209-24.

15 Heidegger M. Sein und Zeit (1927). Tübingen: Niemeyer; 1979.

16 Pöggeler O. Heidegger und die hermeneutische Philosophie. Freiburg: Alber; 1983.

17 Schmidt-Degenhard M. Zur Standortbestimmung einer anthropologischen Psychiatrie. Fortschr Neurol Psychiatr. 1997 Oct;65(10): 473-80.

18 Blankenburg W. Der Verlust der natürlichen Selbstverständlichkeit. Stuttgart: Enke; 1971.

19 Bürgy M. The concept of psychosis: historical and phenomenological aspects. Schizophr Bull. 2008 Nov;34(6):1200-10.

20 Schmidt-Degenhard M. Anthropologische Aspekte psychischer Erkrankungen. In: Möller HJ, Laux G, Kapfhammer HP, editors. Psychiatrie, Psychosomatik, Psychotherapie. Volume 1. 4th ed. Berlin, Heidelberg: Springer; 2011. pp. 383-96.

21 Möller HJ, Laux G, Kapfhammer HP, editors Psychiatrie, Psychosomatik, Psychotherapie. 5th ed. Berlin: Springer; 2016. vol. 1, p. 1-15.

22 Jaspers K. Allgemeine Psychopathologie. Berlin: Springer; 1913

23 Jaspers K. Allgemeine Psychopathologie. 7th Vol. Berlin: Springer; 1959
24 Ströker E. Husserl's principle of evidence: The significance and limitations of a methodological norm of phenomenology as a science. In: de Warren N, Toadvine T, editors. Contributions to phenomenology. Volume 30. Dordrecht: Springer; 1997. pp. 45-81.

25 Bürgy M. The Live-World of the ObsessiveCompulsive Person. In: Stanghellini G, Raballo A, Broome M, Fernandez AV, Fusar-Poli P, Rosfort R, editors. The Oxford Handbook of Phenomenological Psychopathology. Online Publication Date; Sep 2018.

26 Spitzer M. Allgemeine Subjektivität und Psychopathologie. Frankfurt: Haag \& Herchen; 1985.

27 Esquirol E. Des maladies mentales considérées sous les rapports medical, hygiénique et médico-legal. Paris: Bailliére; 1839.

28 v. Krafft-Ebing R. Beiträge zur Erkennung und richtigen forensischen Beurteilung krankhafter Gemütszustände für Ärzte, Richter und Verteidiger. Erlangen: Enke; 1867.

29 Oberbeck A, Stengler K, Steinberg H. Die Geschichte der Zwangserkrankung: Ihre Stellung im Wandel der psychiatrischen Formenlehre bis Anfang des 20. Jahrhunderts. Fortschr Neurol Psychiatr. 2013 Dec;81(12): 706-14.

30 Griesinger W. Über einen wenig bekannten psychopathischen Zustand. Arch Psychiatr Nervenkr. 1868;1(3):626-35.

31 Westphal C. Über Zwangsvorstellungen. Berl Klin Wochenschr. 1877;46:669-72.

32 Oberbeck A, Steinberg H. Sind die aktuellen Konzepte der Zwangsstörung ein Novum? Von Westphal (1877) und Thomsen (1895) zur ICD-10 und zum DSM-5. Nervenarzt. 2015 Sep;86(9):1162-7.

33 Schneider K. Begriffliche Untersuchung über den Zwang. Allg Z Psychiatr. 1939;112:17-24.

34 Dilling $\mathrm{H}$, Mombour W, Schmidt MH, editors. Internationale Klassifikation psychischer Störungen: ICD-10. Bern: Huber; 1991.

35 APA. Diagnostic and statistical manual of mental disorders: DSM-5. Washington (DC): American Psychiatric Publishing; 2013.

36 Shavitt RG, de Mathis MA, Oki F, Ferrao YA, Fontenelle LF, Torres AR, et al. Phenomenology of OCD: lessons from a large multicenter study and implications for ICD-11. J Psychiatr Res. 2014 Oct;57:141-8.

37 APA. Diagnostic and statistical manual of mental disorders: DSM-IV. Washington (DC): American Psychiatric Publishing; 1994.

38 Kapfhammer HP. Zwangsstörung. In: Möller H-J, Laux G, Kapfhammer H-P, editors. Psychiatrie, Psychosomatik, Psychotherapie. 4th ed. Heidelberg: Springer; 2011. vol. 2, p. 571604.

39 Ehret AM, Berking M. DSM-IV und DSM-5: washat sich tatsächlich verändert? Verhaltenstherapie. 2013;23(4):258-66.

40 Eisen JL, Rasmussen SA. Obsessive compulsive disorder with psychotic features. J Clin Psychiatry. 1993 Oct;54(10):373-9.

41 Janet P. Les obsessions et la psychasthénie. Paris: Alcan; 1903.
42 Binder H. Zur Psychologie der Zwangsvorgänge (1931). Ausgewählte Arbeiten. Bern: Huber; 1971. vol. 1, p. 221-317.

43 Lang H. Der gehemmte Rebell. Struktur, Psychodynamik und Therapie von Menschen mit Zwangsstörungen. Stuttgart: Klett-Cotta; 2015.

44 Hoffmann N, Hofmann B. Expositionen bei Ängsten und Zwängen. 4th ed. Weinheim, Basel, Berlin: Beltz; 2018.

45 Bürgy M. Obsession in the strict sense: A helpful psychopathological phenomenon in the differential diagnosis between obsessivecompulsive disorder and schizophrenia. Psychopathology. 2007;40(2):102-10.

46 Bloch MH, Landeros-Weisenberger A, Rosario MC, Pittenger C, Leckman JF. Meta-analysis of the symptom structure of obsessivecompulsive disorder. Am J Psychiatry. 2008 Dec;165(12):1532-42.

47 Leckman JF, Denys D, Simpson HB, MataixCols D, Hollander E, Saxena S, et al. Obsessive-compulsive disorder: a review of the diagnostic criteria and possible subtypes and dimensional specifiers for DSM-V. Depress Anxiety. 2010 Jun;27(6):507-27.

48 Kordan A, Lotz-Rambaldi W, MucheBorowski C, Hohagen F. S3-Leitlinie Zwangsstörungen (DGPPN). Berlin, Heidelberg: Springer; 2015.

49 Mataix-Cols D, Rosario-Campos MC, Leckman JF. A multidimensional model of obsessive-compulsive disorder. Am J Psychiatry. 2005 Feb;162(2):228-38.

50 v. Gebsattel VE. Die Welt des Zwangskranken. In: Prolegomena einer medizinischen Anthropologie. Berlin: Springer; 1954. pp. 74 128

51 Ecker W, Gönner S. Das Unvollständigkeitsgefühl. Neuentdeckung eines alten psychopathologischen Symptoms bei Zwangserkrankungen. Nervenarzt. 2006 Sep;77(9): 1115-20.

52 Ecker W, Gönner S. Incompleteness and harm avoidance in OCD symptom dimensions. Behav Res Ther. 2008 Aug;46(8):895904

53 Lang H. Zur Struktur und Therapie der Zwangsneurose. Psyche (Stuttg). 1986 Nov: 40(11):953-70.

54 Quint H. Die Zwangsneurose aus psychoanalytischer Sicht. Berlin, Heidelberg: Springer; 1988. https://doi.org/10.1007/978-3-64273198-3.

55 Bürgy M. The narcissistic function in obsessive-compulsive neurosis. Am J Psychother. 2001;55(1):65-73.

56 Pelegrina H. Psicopatologia Regional. Buenos Aires: Editorial Polemos; 2017. pp. 466-72.

57 Abramowitz JS, Fabricant LE, Jacoby RJ. Obsessive-Compulsive Disorder. In: Craighead WE, Miklowitz DJ, Craighead LW, editors. Psychopathology: History, diagnosis, and empirical foundations. 2nd ed. Hoboken (New Jersey): Wiley; 2013. pp. 80-107. 
58 Salkovskis PM. Understanding and treating obsessive-compulsive disorder. Behav Res Ther. 1999 Jul;37 Suppl 1:S29-52.

59 Rachman S. A cognitive theory of obsessions. Behav Res Ther. 1997 Sep;35(9):793-802.

60 Bürgy M. Psychopathology of obsessive-compulsive disorder: a phenomenological approach. Psychopathology. 2005 Nov-Dec; 38(6):291-300.

61 Mancebo MC, Eisen JL, Grant JE, Rasmussen SA. Obsessive compulsive personality disorder and obsessive compulsive disorder: clinical characteristics, diagnostic difficulties, and treatment. Ann Clin Psychiatry. 2005 OctDec;17(4):197-204

62 Gordon OM, Salkovskis PM, Oldfield VB, Carter N. The association between obsessive compulsive disorder and obsessive compulsive personality disorder: prevalence and clinical presentation. Br J Clin Psychol. 2013 Sep 52(3):300-15.

63 Coles ME, Pinto A, Mancebo MC, Rasmussen SA, Eisen JL. OCD with comorbid OCPD: a subtype of OCD? J Psychiatr Res. 2008 Mar 42(4):289-96

64 Lochner C, Serebro P, van der Merwe L, Hemmings S, Kinnear C, Seedat S, et al. Comorbid obsessive-compulsive personality disorder in obsessive-compulsive disorder (OCD): a marker of severity. Prog Neuropsychopharmacol Biol Psychiatry. 2011 Jun;35(4):108792.

65 Maina G, Albert U, Salvi V, Pessina E, Bogetto F. Early-onset obsessive-compulsive disorder and personality disorders in adulthood. Psychiatry Res. 2008 Mar;158(2):217-25.

66 Zaudig M. Heterogenität und Komorbidität der Zwangsstörung K. Nervenarzt. 2011;82: 290-8.

67 Summerfeldt LJ. Understanding and treating incompleteness in obsessive-compulsive disorder. J Clin Psychol. 2004 Nov;60(11):115568.

68 Ecker W, Kupfer J, Gönner S. Incompleteness and harm avoidance in $\mathrm{CD}$, anxiety and depressive disorders, and non-clinical controls. J Obsessive Compuls Relat Disord. 2014;3(1): $46-51$

69 Summerfeldt LJ, Kloosterman PH, Antony MM, Swinson RP. Examining an obsessivecompulsive core dimensions model: structural validity of harm avoidance and incompleteness. J Obsessive Compuls Relat Disord. 2014 3(2):83-94.
70 Ecker W, Gönner S. Aktueller Forschungsstand zum Unvollständigkeitserleben bei Zwangsstörungen. Verhaltenstherapie. 2017; 27(2):120-8.

71 Hoffmann N. Zwänge und Depressionen. Pierre Janet und die Verhaltenstherapie. Berlin, Heidelberg: Springer; 1998.

72 Ecker W, Kupfer J, Gönner S. Selbstbezogenes Unvollständigkeitserleben bei Zwangsstörungen. Verhaltenstherapie. 2013;23(1):12-21

73 Sibrava NJ, Boisseau CL, Eisen JL, Mancebo MC, Rasmussen SA. An empirical investigation of incompleteness in a large clinical sample of obsessive compulsive disorder. J Anxiety Disord. 2016 Aug;42:45-51.

74 Ecker W, Kupfer J, Gönner S. Incompleteness as a link between obsessive-compulsive personality traits and specific symptom dimensions of obsessive-compulsive disorder. Clin Psychol Psychother. 2014 Sep-Oct;21(5):394402.

75 Summers BJ, Matheny NL, Cougle JR. 'Not just right' experiences and incompleteness in body dysmorphic disorder. Psychiatry Res. 2017 Jan;247:200-7.

76 Freud S. Bemerkungen über einen Fall von Zwangsneurose (1909). Gesammelte Werke. Frankfurt: Fischer; 1941. vol. 14, p. 379-463.

77 v. Gebsattel VE. Die anakastische Fehlhaltung. In: Imago Hominis. Salzburg: Müller; 1968. p. 173-99.

78 Bürgy M. Zur Psychopathologie des Zwangs. Z Klin Psychol Psychiatr Psychother. 2005;53: 213-29.

79 Dykshoorn KL. Trauma-related obsessivecompulsive disorder: a review. Health Psychol Behav Med. 2014 Jan;2(1):517-28.

80 Ojserkis R, Boisseau CL, Reddy MK, Mancebo MC, Eisen JL, Rasmussen SA. The impact of lifetime PTSD on the seven-year course and clinical characteristics of OCD. Psychiatry Res. 2017 Dec;258:78-82.

81 Külz AK, Voderholzer U. Psychotherapie der Zwangsstörung: was ist evidenzbasiert? Nervenarzt. 2011 Mar;82(3):308-10.

82 Hoffmann N, Hofmann B. Zwanghafte Persönlichkeitsstörung und Zwangserkrankungen. Berlin, Heidelberg: Springer; 2010. https://doi.org/10.1007/978-3-64202514-3.
83 Marsden Z, Lovell K, Blore D, Ali S, Delgadillo J. A randomized controlled trial comparing EMDR and CBT for obsessive-compulsive disorder. Clin Psychol Psychother. 2018 Jan; 25(1):e10-8.

84 Nazari H, Momeni N, Jariani M, Tarrahi MJ Comparison of eye movement desensitization and reprocessing with citalopram in treatment of obsessive-compulsive disorder. Int $]$ Psychiatry Clin Pract. 2011 Nov;15(4):270-4.

85 Doerr-Zegers O. Space and time in the obsessive-compulsive phenomenon. Psychopathology. 2018;51(1):31-7.

86 Straus E. Ein Beitrag zur Pathologie der Zwangserscheinungen. Monatsschr Psychiatr Neurol. 1938;98(2):61-81.

87 Skoog G. Onset of anancastic conditions. A clinical study. Acta Psychiatr Scand Suppl. 1965;184:1-82.

88 Schwidder W. Klinik der Neurosen. In: Kisker KP, Mayer JE, Müller C, Strömgren E, editors. Psychiatrie der Gegenwart. 2nd ed. Berlin: Springer; 1972. vol. II/1, p. 351-415.

89 Hoffmann N, Hofmann B. Wenn Zwänge das Leben einengen. 15th ed. Berlin, Heidelberg: Springer; 2017. https://doi.org/10.1007/978 3-662-52850-1.

90 Menzies RG, Menzies RE, Iverach L. The role of death fears in obsessive-compulsive disorder. Aust Clin Psychol. 2015;1:6-11.

91 Menzies RE, Dar-Nimrod I. Death anxiety and its relationship with obsessive-compulsive disorder. J Abnorm Psychol. 2017 May; 126(4):367-77.

92 Iverach L, Menzies RG, Menzies RE. Death anxiety and its role in psychopathology: reviewing the status of a transdiagnostic construct. Clin Psychol Rev. 2014 Nov;34(7): 580-93.

93 Meyer JE. Tod und Neurose. Göttingen: Vandenhoeck \& Ruprecht; 1973.

94 Meyer JE. Die Todesthematik in der Entstehung und im Verlauf von Zwangsneurosen. Z Psychother Med Psychol. 1975;25:124-8.

95 Meyer JE. Todesangst und das Todesbewußtsein der Gegenwart. 2nd ed. Berlin, Heidelberg, New York: Springer; 1982. https://doi. org/10.1007/978-3-642-93205-2.

96 Lang H. Ätiologie und Aufrechterhaltung der Zwangsstörungen aus psychodynamischer Sicht. In: Ambühl H, editor. Psychotherapie der Zwangsstörungen. Stuttgart, New York: Thieme; 1998. pp. 23-30. 